\title{
DISCOVERY OF FEDERAL INCOME TAX RETURNS AND THE NEW "QUALIFIED" PRIVILEGES
}

Federal income tax returns contain a variety of information potentially useful to a taxpayer's adversary in civil litigation. A taxpayer's federal return must list his income "from whatever source derived" 1 and typically contains information about the taxpayer's marital status, dependents, business dealings, investments, religious affiliations, charitable inclinations, property holdings, and debt obligations. ${ }^{2}$ The Federal Rules of Civil Procedure provide for discovery of nonprivileged documents "reasonably calculated to lead to the discovery of admissible evidence," even if the docuinents themselves would not be admissible. ${ }^{3}$ The discovery provisions of the Federal Rules are to be read liberally and in favor of broad pretrial discovery. ${ }^{4}$ Nevertheless, a taxpayer may have formed an expectation that the personal information required on his return will reinain

1. I.R.C. $\$ 61$ (1982).

2. An individual income tax return may contain an immense anount of information about its filer. By the time he answers the first seven questions on the form, the taxpayer has identified himself and his address, social security number, marital status, and children or other dependents. By responding to the next eight questions, he exposes his entire gross incoine for the year, at least in summary form. Before he has completed the first half of the first page of Form 1040, he has revealed the skeletal outline of his personal and financial life.

The more attachments he affixes, the more vulnerable he becomes. There is likely to be a W-2 form, through which others inay discover vital facts about his employenent. By reviewing Schedule A to Form 1040, a reader may learn whether the taxpayer or his family are [sic] under medical and psychiatric care. It also may reveal the filer's religious affiliation, the objects and degree of his eleenosynary inclinations, the sources of his borrowed inoney, his union inembership, his political leanings, and many other facets of his personal and private life.

A close reading of Schedule B in conjunction with proper financial publications may reveal an entire investment portfolio-not just its general content, but the taxpayer's precise holdings.

Report on Administrative Procedures of the Internal Revenue Service to the JudiCial Conference of THe United STATES, S. Doc. No. 266, 94th Cong., 2d Sess. 827-28 (1975) [hereinafter cited as ADMINISTRATIVE REPORT].

3. FED. R. CIv. P. 26(b)(1).

4. Hickman v. Taylor, 329 U.S. 495, 507 (1947). 
private..$^{5}$ Discovery of federal income tax returns, ${ }^{6}$ therefore, involves a conflict between the taxpayer's privacy expectations and the policy favoring broad civil discovery.

No statute or regulation resolves this conflict. Sections 6103 and 7213 of the Internal Revenue Code, ${ }^{7}$ which pertain to the confidentiality of taxpayer filings, have generally been interpreted not to confer a privilege upon tax returns and return information in the possession of the taxpayer. ${ }^{8}$ Moreover, neither the Privacy Act of $1974^{9}$ nor the Tax Reform Act of $1976^{10}$ limited discovery of tax return infornation by a taxpayer's opponent in a civil suit. ${ }^{11}$ Notwithstanding

5. ADMinistrative REPORT, supra note 2, at 328-29.

6. "Return" and "return information" are given a technical meaning at I.R.C. $\$ 6103(\mathrm{~b})(1)-$ (2) (1982). Benedict \& Lupert, Federal Income Tax Returns-The Tension Between Government Access and Confidentiality, 64 CoRneld L. Rev. 940, 950 n.53 (1979); see generally Corey, Confidentiality of Tax Returns, 36 ANNUAL N.Y.U. INSTITUTE ON FEDERAL TAXATION 1265, 126972 (1978).

7. The "general rule" is that "returns and return information shall be confidential, and except as authorized by this title-(1) no officer or employee of the United States, [and] (2) no officer or employee of any State . . shall disclose any return or return information obtained by him im any manner . . . " I.R.C. \& 6103(a). The exceptions to the general rule permit disclosure of returns and return information to such persons as the taxpayer may designate im writing, I.R.C. $\S 6103(\mathrm{c})$, to the taxpayer himself, I.R.C. $\$ 6103(\mathrm{e})(\mathrm{l})(\mathrm{A})(\mathrm{i})$, to his spouse on stated conditions, I.R.C. $\$ 6103(\mathrm{e})(1)(\mathrm{A})(\mathrm{iii})$, to either party to a joint return, I.R.C. $\$ 6103(\mathrm{e})(1)$ (B), to a partner (with respect to a partnership return), I.R.C. $\$ 6103(\mathrm{e})(1)(\mathrm{C})$, to any person designated by resolution of the board of directors, a corporate officer in stated circumstances, or a bona fide shareholder of more than one percent of the corporation's stock im stated circumstances (with respect to a corporate return), I.R.C. $\$ 6103(\mathrm{e})(1)(\mathrm{D})(\mathrm{i})$, (ii), (iii), to a trustee, executor or beneficiary, in stated circumstances (with respect to the return of a trust or estate), I.R.C. $\$ 6103(e)(1)(E),(F)$, and, upon court order, to federal officers and employees undertaking nontax federal criminal investigations, I.R.C. \$6103(i)(1)(A).

Provisions penalizing violations of Section 6103 are found at I.R.C. $\$ 7213$ (1982). Sohcitors and publishers of unlawful disclosures are subject to fines not exceeding $\$ 5000$ and terms of imprisonment not exceeding five years, plus costs of prosecution. Id. \$7213(a)(3), (4).

8. E.g., St. Regis Paper Co. v. Umited States, 368 U.S. 208, 219 (1961); Preımum Serv. Corp. v. Sperry \& Hutchinson Co., 511 F.2d 225, 229 (9th Cir. 1975); Eastern Auto Distribs., Inc. v. Peugeot Motors of Am., Inc., 96 F.R.D. 147, 148 (E.D. Va. 1982); Kingsley v. Delaware, L. \& W. R.R., 20 F.R.D. 156, 158 (S.D.N.Y. 1957); Connecticut Importing Co. v. Continental Distilling Corp., 1 F.R.D. 190, 192 (D. Conn. 1940) (construmg $\S 55$ of the Internal Revenue Code of 1939, which is the predecessor of the current $\$ 6103$ of the Internal Revenue Code of 1954). Contra Austin v. Aluminum Co. of Am., 15 F.R.D. 490, 490 (E.D. Tenn. 1954); O'Connell v. Olsen \& Ugelstadt, 10 F.R.D. 142, 143 (N.D. Ohio 1949).

9. 5 U.S.C. \& $552 \mathrm{a}(1982)$.

10. Pub. L. No. 94-455, 90 Stat. 1520, 1667-87 (codified at I.R.C. $\$ \S 6103,7213$ (1982)).

11. The Privacy Act of 1974 prohibits the federal government from disclosing information about an individual without his consent. The Act, however, specifically exempts disclosure which would be "pursuant to the order of a court of competent jurisdiction." 5 U.S.C. \$ 552a(b)(11). See Benedict \& Lupert, supra note 6, at 949. ("While tax returns appear to be covered by the Privacy Act, the Act's broad exceptions negate any practical effect.").

The Senate Committee Report on the Tax Reform Act of 1976 stated that "[b]y this amendment, the Committee does not itnend [sic] to limit the right of an agency (or other party) to obtain returns or return information directly from the taxpayer through the applicable discovery 
the absence of any express congressional or administrative ${ }^{12}$ mandate to limit discovery of tax returns, however, some courts have developed a "qualified" tax return privilege. 13

This note first discusses the judicial development of a "qualified" privilege for tax returns. ${ }^{14}$ The two policy foundations for the privilege are (a) protecting taxpayer privacy, and (b) encouraging the filing of full and accurate tax returns, in compliance with federal law. ${ }^{15}$ The note then discusses the general doctrine of "qualified" privileges that is einerging in federal courts. ${ }^{16}$ The emerging "qualified" privileges typically relieve the party opposing discovery of his initial burden of showing good cause why discovery should be denied. Moreover, it places upon the party seeking discovery a burden of showing the relevance of the inforination sought and the absence of alternative means of discovery. The note argues that courts should use the standard governing the creation of the traditional "absolute" privileges to determine whether to recognize a claim of "qualified" privilege. ${ }^{17}$ The note then critically analyzes the "qualified" tax return privilege according to the traditional standard. ${ }^{18}$

The policy of encouraging taxpayer compliance, which nany courts advance in support of the "qualified" tax return privilege,

procedures.” S. REP. No. 938, 94th Cong., 2d Sess. 331, reprinted in 1976 U.S. Code CoNa. \& AD. News 3439, 3761 (emphasis added). See also Corey, supra note 6, at 1299-1300 (confidentiality provisions of the Internal Revenue Code do not prohibit the obtaining of returns and return information directly from the taxpayer). The cases are in agreement. See Credit Life Ins. Co. v. Uniworld Ins. Co., 94 F.R.D. 113, 119 (S.D. Ohio 1982) (legislative history of the 1976 Tax Reform Act does not indicate that Congress considered according absolute privilege to tax returns); Houlihan v. Anderson-Stokes, Inc., 78 F.R.D. 232, 233-34 (D.D.C. 1978) (the Tax Reform Act of 1976 "only restricts the dissemination of tax returns by the government . . , copies in the hands of a taxpayer" are discoverable); But of. Payne v. Howard, 75 F.R.D. 465, 469 n.4 (D.D.C. 1977) ("Nothing in the 1976 amendments to the tax code diminishes the confidential nature of federal tax returns. In fact, the opposite appears true.").

12. Treasury regulations provide that disclosure of tax return information to the designee of the taxpayer "shall not be made . . . if the Service determines that the disclosure would seriously inpair Federal tax administration." Treas. Reg. § 301.6103(c)-1(c) (1984). There is no analogous restriction where the taxpayer requests a copy for his own use. I.R.C. $\S 6103(e)(1)(A)(i)(1982)$. The courts that order discovery of tax return information typically require the taxpayer to obtain a copy of his return from the IRS-if he has not retaimed one-and then to make that copy available to his adversary. E.g., Reeves v. Pennsylvania R.R. Co., 80 F. Supp. 107, 108-09 (D. Del. 1948).

13. The term "qualified" privilege was first applied to discovery of income tax rcturns in Eastern Auto Distribs., Inc. v. Peugeot Motors of Am., Inc., 96 F.R.D. 147, 148 (E.D. Va. 1982).

14. See infra notes $26-64$ and accoinpanying text.

15. See infra notes $65-78$ and accompanying text.

16. See infra notes 79-97 and accoinpanying text.

17. See infra notes 98-108 and accompanying text.

18. See infra notes 109-39 and accompanying text. 
embodies two distimct concerns. ${ }^{19}$ The first, that of encouraging full and accurate reporting of tax deductions, is found not to be in need of judicial assistance. ${ }^{20}$ The second, that of encouraging full and accurate reporting of income, is found to derive from what many courts regard as a national policy of maximizing federal revenues. ${ }^{21}$ The note argues that the policy of maximizing federal revenue cannot be served to any significant degree by a "qualified" tax return privilege. ${ }^{22}$

The policy of guarding taxpayer privacy, which some courts mvoke to justify a "qualified" privilege, is shown not to justify special treatment of tax returns as agamst other financial information. ${ }^{23}$ Taxpayer privacy is, moreover, shown to be sufficiently well protected from discovery abuse by the standard structure of Rule $26 .{ }^{24}$ The note concludes that a "qualified" privilege for tax returns is an unjustified departure from the norms of discovery under the federal rules. ${ }^{25}$

\section{ORigin and Evolution of The “Qualified" Privilege for FEDERAL INCOME TAX RETURNS}

\section{A. The Early Cases.}

Section 6103(a) of the Internal Revenue Code provides that tax returns and return information "shall be confidential." 26 The early cases were divided in their application of section $6103^{27}$ to civil discovery of tax returns. In Connecticut Importing Co. v. Continental Distilling Corp. ${ }^{28}$ the court held that nothing im section 6103 or the regulations issued under it "precludes a court of competent jurisdiction from requiring a disclosure of a tax return by the taxpayer in connection with civil litigation to which the taxpayer is a party."29 Precisely the opposite conclusion was reaclied, however, by the court in $\mathrm{O}^{\prime} \mathrm{Connell} v$. Olsen \& Ugelstadt ${ }^{30}$ which held that until Congress or the Treasury provided otherwise, tax returns would be immune from civil discovery. ${ }^{31}$ Although the Connecticut Importing view of section 6103 gained

\footnotetext{
19. See infra notes $65-78$ and accompanying text.

20. See infra notes $114-16$ and accompanying text.

21. See infra note 113 and accompanying text.

22. See infra notes 117-19 and accompanying text.

23. See infra notes 120-39 and accompanying text.

24. See infra notes 110-11 and accompanying text.

25. See infra text following note 139 .

26. I.R.C. $\$ 6103($ a) (1982).

27. Section 55 of the Internal Revenue Code of 1939 was the predecessor of the current $\$ 6103$ of the Internal Revenue Code of 1954.

28. 1 F.R.D. 190 (D. Conn. 1940).

29. Id. at 192

30. 10 F.R.D. 142 (N.D. Ohio 1949).

31. Id. at 142 .
} 
the support of most courts, ${ }^{32} \mathrm{O}^{\circ} \mathrm{Connell} \mathrm{had} \mathrm{at} \mathrm{least} \mathrm{one} \mathrm{follower,}{ }^{33}$ and other courts denied discovery of tax returns on grounds other than statutory privilege, chiefly, for failure to show "good cause," which until 1970 was required to be shown by the movant for an order to compel discovery. ${ }^{34}$ In denymg motions to compel discovery, courts have noted that the information was available from alternative sources ${ }^{35}$ or by the "intelligent use" of other discovery devices, ${ }^{36}$ or that the information was of doubtful relevance. ${ }^{37}$ By the time the inapplicability of section 6103 to private litigants was finally settled by the Supreme Court's dictum in St. Regis Paper Co. v. United States, ${ }^{38}$ a doctrime of "qualified" privilege had taken hold independently of any supposed statutory basis.

32. See, e.g., The Sultana, 77 F. Supp. 287, 288 (W.D.N.Y. 1948); Reeves v. Pennsylvania R.R. Co., 80 F. Supp. 107, 108 (D. Del. 1948).

33. Austin v. Aluminum Co. of Am., 15 F.R.D. 490, 490 (E.D. Tenn. 1954).

34. It could be argued that the new "qualified" privileges that are increasingly appearing in federal practice are but a recrudescence of the old, discredited "gocd cause" requirement. See generally FED. R. CIV. P. 34 advisory committee notes; infra notes $105-08$ and accounpanying text.

35. See Welty v. Clute, 2 F.R.D. 429, 430 (W.D.N.Y. 1939) (unotion to counpel production of income tax returns denied; finding that that books and records required to be produced reveal income so far as relevant).

36. O'Connell v. Olsen \& Ugelstadt, 10 F.R.D. at 143.

37. Richland Wholesale Liquors v. Joseph E. Seagram \& Sons, 40 F.R.D. 480, 483 (D.S.C. 1966).

38. 368 U.S. 208, 218-19 (1961). Compare that section of the Code which deals with disclosure of tax return information in a state or federal judicial or administrative tax proceeding, and limits disclosure

[t]o the extent required by an order of a court pursuaut to section 3500 of title 18, United States Code, or Rule 16 of the Federal Rules of Criminal Procedure, such court being authorized in the issuance of such order to give due consideration to congressional policy favoring the confidentiality of returns and return information as set forth in this tille.

I.R.C. $\$ 6103(\mathrm{~h})(4)(\mathrm{D})$ (1982) (einphasis added). It could be argued that the dictum in St. Regis did not insulate the conduct of discovery in private civil litigation from the reach of this confideutiality policy. Such an argument has, however, scveral weaknesses. The St. Regis court, though in dictum, stated that the language of section 6103 had no application to discovery in private litigation. Second, section 6103(h)(4)(D) applies to disclosure in judicial and administrative tax proceedings. No wider application appears to have been intended. Third, Congress quickly reacted to the St. Regis decision, as it pertained to census reports, by creating an absolute "census report" privilege. Act of Oct. 15, 1962, Pub. L. No. 87-813, 76 Stat. 922,922 (codified at 13 U.S.C. \$ 9 (1982)); United States v. American Tel. \& Tel. Co., 86 F.R.D. 603, 648 (D.D.C. 1979).

Cougress has not aunended the relevant portions of the Internal Revenue Code, although

it has been afforded inany opportunities to do so. . . Given the decision in St. Regis

Paper Co. v. United States and the repeated failure of Congress to alter the discoverable status of tax returns, as observed in that case . . the conclusion must be drawn that . . . tax returns are subject to discovery in civil litigation between private parties.

Credit Life Ins. Co. v. Uniworld Ins. Co., 94 F.R.D. 113, 119 (S.D. Ohio 1982); accord Maggio v. Hynes, 423 F. Supp. 144, 146 (E.D.N.Y. 1970) (Congress has not acted to disturb decisions exposing tax returns to discovery by private litigants); $f$. United States v. Arthur Young \& Co., 104 S. Ct. 1495, 1501 (1984) (tax accrual workpapers prepared by indepeudent auditor are discoverable nnder Rule $26(\mathrm{~b})(\mathrm{l})$ by private plaintiff in securities hitigation). 


\section{B. The Kingsley Rule.}

The first case to establish a "qualified" tax return privilege without invoking explicit statutory authority was Kingsley v. Delaware, Lackawanna \& Western Railroad. ${ }^{39}$ In Kingsley, decided four years before St. Regis, the defendant moved to compel production of the plaintiff's tax returns in a suit for recovery of lost earnings. The court noted the disarray of the earlier cases, criticized $O^{\prime}$ Connell for reading a nonwaivable privilege into section 6103,40 and concluded that the "better reasoned view" was that "where a hitigant himself tenders an issue as to the amount of his income, there is no privilege against the disclosure of his tax returns." 41 The court found that disclosure under these circumstances was consistent with section 6103 because "the purpose of the statute is to prevent the disclosure of confidential information to those who do not have a legitimate interest in it."42 By bringing suit upon a claim of lost earnings, the taxpayer had given his adversary a "legitimate imterest" in his income and thus waived a privilege he would otherwise have enjoyed. ${ }^{43}$

Although some courts have applied the Kingsley rule without modification, ${ }^{44}$ others-faced with more comphcated facts-have made adjustments. In Shaver v. Yacht Outward Bound, ${ }^{45}$ the court invoked the Kingsley rule ${ }^{46}$ even though the plaimtiff had not directly made his income an issue. The plaintiff in Shaver had been injured while a guest on a yacht, and sought its owner's federal tax return to discover whether the expenses of maintaining the boat were claimed as business deductions. The plaintiff hoped to show that the owner's employer could be held liable on a theory of respondeat superior. In ordering the

39. 20 F.R.D. 156 (S.D.N.Y. 1957).

40. Id at 159 .

41. Id at 158.

42. Id.

43. Not all commentators read Kingsley as a "waiver" case. Compare Developments in the Law-Discovery, 74 HARv. L. Rev. 940, 1011 \& n.558 (1961) (waiver) with Conklin, Income Tax Returns and the Federal Rules, in TRIAL LAW. GUIDE 1, 5 (J. Kennelly ed. 1982) (relevance). Kingsley both rejects and embraces the assumption that privilege law applies to tax returns. Unless he has been misnnderstood, Judge Bryan argued both that no privilege existed and that it had been waived. Cases following Kingsley agreed that there was no "absolute" privilege but seemed to find the language of privilege a convenient shorthand for a variety of disconnected concerns that needed to be addressed before discovery would be allowed.

44. See, e.g., Federal Sav. \& Loan Ins. Corp. v. Kreuger, 55 F.R.D. 512 , 514 (N.D. Ill. 1972) ("It is the opinion of this court that the case of Kingsley . . . represents the best view."); Wiesenberger v. W.E. Hutton \& Co., 35 F.R.D. 556, 557 (S.D.N.Y. 1964) ("income tax returns should be ordered produced 'where a litigant himself tenders an issue as to the amount of damages" ").

45. 71 F.R.D. 561 (E.D. Ill. 1976).

46. Id at 563. The court does not cite Kingsley but rather Federal Sav. \& Loan Ins. Corp. v. Kreuger, 55 F.R.D. 512, 514 (N.D. Ill. 1972), which adopts Kingsley. 
production of the tax return, the court modified the Kingsley rule in two ways. First, the court held that the party resisting discovery cannot claim a privilege if his returns would "cast significant hight" 47 on issues he raised. Second, by holding that the taxpayer waives his privilege if tax return information is relevant to any factual issue "raised by his denials," 48 the court, in effect, required the taxpayer to admit to those of his adversary's pleadings to which his tax returns may be relevant or else risk waiver.

\section{The Cooper Rule.}

The second important "qualified" tax return privilege case was Cooper v. Hallgarten \& Co. ${ }^{49}$ In Cooper, a securities fraud case, the plaintiff sought a protective order denying the defendant access to his tax returns, which the defendant argued would show that the plaintiff's motivation in investing was to shelter income. In its analysis, the court applied a rule quite different from that of the Kingsley case. Noting the conflict between the policies favoring extensive discovery, on the one hand, and disfavoring disclosure of confidential taxpayer information, on the other, the court devised a rule intended to put the two in proper balance: "[T] he production of tax returns should not be ordered unless it clearly appears they are relevant to the subject matter of the action or to the issues raised thereunder, and further, that there is a compelling need therefor because the information contained therein is not otherwise readily obtainable." 50

Later cases have applied this two-part rule, but with differing thresholds and burdens of proof. In Eastern Auto Distributors v. Peugeot Motors of America, Inc., ${ }^{51}$ for example, the court required that

47. Shaver, 71 F.R.D. at 564.

48. Id.

49. 34 F.R.D. 482 (S.D.N.Y. 1964).

50. Id. at 484 . The rule closely resembles the formulae utilized by courts until 1970 to interpret the showing of "good cause" required of parties seeking discovery under Rule 34. See supra note 34. FED. R. CIV. P. 26(c) advisory committee note (1970 amendment). The elimination of the good cause requirement was imdertaken simultaneously with the rearrangement of Rule 26 to incorporate former Rule 30(b), "changed to give it application to discovery generally." Id. It appears that these amendments were intended to apply the mechamism of Rule $26(\mathrm{c})$ to all documents-other than attorney work-product-formerly shielded from discovery by application of the "good cause" requirement of Rule 34. Accord 8 C. Wright \& A. Miller, Federal PracTICE AND PROCEDURE $\S 2205$ at 602-06 (1970) ("As a result [of the 1970 amendments] . . . documents that are not trial preparation are freely discoverable under Rule 34.").

Nevertheless, it is also plain that the 1970 amendments were not intended to disapprove special treatment of imcome tax returns under Rule $26(\mathrm{c})$ when "imterests of privacy may call for a measure of extra protection." FED. R. CIV. P. 26(c) advisory committee notes (1970 amendinents).

51. 96 F.R.D. I47 (1982). 
the party seeking discovery show some, rather than clear, relevance. ${ }^{52}$ The court further held that once the party seeking discovery has made his showing of relevance, his opponent bears the burden of showing that the information sought is available from other sources. Should his opponent ineet that burden, discovery will not be ordered unless the party seeking discovery shows the court that a "good faith" examination of the alternative sources indicated by his opponent fails to disclose the information desired. ${ }^{53}$

\section{Other Standards.}

Other courts that restrict discovery of tax returns invoke cautionary phrases, such as that tax return information ought not be "indiscriminately disclosed" 54 in civil discovery, or that discovery may be had in "appropriate circumstance" 55 but ought not be "routinely required." 56 Often, the analyses applied in these cases trace the Cooper or Kingsley rules, ${ }^{57}$ a variant of one or the other, ${ }^{58}$ or a combination of the two. ${ }^{59}$ Other courts, following Weisenberger v. W.E. Hutton \& $\mathrm{Co} .{ }^{60}$ have held that tax return information is discoverable only where "clearly required in the interests of justice." 61 This formula has also been suppleinented by other vehicles of analysis, ${ }^{62}$ but it differs from other "qualified" tax return privilege standards in that it seeins to sanc-

52. Id. at 148 .

53. Id. at 149.

54. Payne v. Howard, 75 F.R.D. 465,469 (D.D.C. 1977)

55. Heathman v. United States Dist. Ct., 503 F.2d 1032, 1035 (9th Cir. 1974).

56. Troglione v. McIntyre Aviation, Inc., 60 F.R.D. 511, 512 (W.D. Pa. 1973).

57. Federal Sav. \& Loan Ins. Corp. v. Kreuger, 55 F.R.D. 512,514 (N.D. I11. 1972); Richland Wholesale Liquors, Inc. v. Joseph E. Seagram \& Sons, 40 F.R.D. 480, 483 (D.S.C. 1966) (Cooper not met, even assuming Kingsley niet).

58. See, e.g., Eastern Auto Distribs. v. Peugeot Motors of Am., 96 F.R.D. 147, 148-49 (E.D. Va. 1982) (discovery may be had in "appropriate circumstances," determined by a variant of the Cooper test); Eglin Fed. Credit Union v. Canto, Fitzgerald Sec. Corp., 91 F.R.D. 414, 416-17 (N.D. Ga. 1981) (federal policy limits discovery to "appropriate circumstances," but denied on grounds consistent with Cooper; party seeking discovery failed to show unavailability elsewhere); Smith v. Bader, 83 F.R.D. 437, $438-39$ (S.D.N.Y. 1979) (returns not "routimely" discoverable, but party resisting discovery has to lave put income in issue, as under Kingsley).

59. See, e.g., Mitsui \& Co. v. Puerto Rico Water Resources Auth., 79 F.R.D. 72, 80-81 (D.P.R. 1978) (production of returns not to be "routmely required"; factors relevant to both Cooper and Kingsley lines of analysis are considered); Payne v. Howard, 75 F.R.D. 465, 469-70 (D.D.C. 1977) (discovery noted to liave been limited to "appropriate circumstances"; both Cooper and Kingsley-style analyses applied).

60. 35 F.R.D. 556 (S.D.N.Y. 1964).

61. Id. at 557.

62. See Tele-Radio Sys., Ltd. v. DeForest Elecs., Inc., 92 F.R.D. 371,375 (D.N.J. 1981) (discovery of returns not to be ordered unless "clearly required in the interests of justice"; discovery denied on grounds that information was otherwise available and party resisting discovery had not made imcome an issue). 
tion an especially restrictive departure from the liberal norms of federal discovery.

Still other courts ${ }^{63}$ limit discovery of tax returns upon a showing of good cause by the party resisting discovery, and then only to protect that party from "annoyance, embarrassinent, oppression, or undue burden and expense." This approach is essentially that of Rule 26(c). ${ }^{64}$

\section{E. Policy Rationales Underlying the "Qualified" Tax-Return Privilege.}

Most courts that restrict discovery of federal income tax returns do so at least im part on policy grounds. The Kingsley ${ }^{65}$ and Cooper ${ }^{66}$ opinions advert to a policy against public disclosure of the contents of tax returns-a pohcy "underscored" 67 by sections 6103 and 7213 of the Internal Revenue Code, which penalize government einployees for unlawful disclosure of tax return information.

Taxpayer privacy ${ }^{68}$ and protection of business secrets ${ }^{69}$ have been

63. See, e.g., Lavin v. Becker, 60 F.R.D. 684, 686 (N.D. IIl. 1973). In this securities case, the court considered the defendants' motion to compel production of the plaintiff's tax returns. The court stated that the Federal Rules favor the "broadest possible" discovery, id. at 686, and found that the plaintiff had failed to show that production would be "annoying, burdensome or completely irrelevant to the thrust of the instant hitigation." Id.

The facts of Lavin are similar to those of Wiesenberger. In Wiesenberger the court took the position that returns are not to be discovered unless the party seeking discovery is able to show persuasively that production is "clearly required in the interests of justice." 35 F.R.D. at 557. In Lavin, the burden was reversed.

64. Rule 26(c) states:

Upon motion by a party or by the person from whom discovery is sought, and for good cause shown, the court . . . may make any order which justice requires to protect a party or person froin annoyance, embarrassment, oppression, or undue burden or expense, imcluding one or more of the following: (1) that the discovery not be had; (2) that the discovery may be had ouly on specified terms and conditions. . .; (4). . . that the scope of discovery be limited to certam matters ....; (7) that a trade secret or other confidential . . . commercial information not be discussed.

FED. R. CIV. P. 26(c) (emphasis added).

65. The Internal Revenue Code of $1954 \ldots$. protects taxpayers against public disclosure of the contents of tax returns. This policy is underscored by the penal provisions of the Code which make it unlawful for any Federal or State officer or employee to divulge such matter "in any manner whatever not provided by law."

Kingsley v. Delaware, L. \& W. R.R., 20 F.R.D. at 158 (emphasis added).

66. "Public poticy favors the nondisclosure of income tax returns. Criminal sanctions for nnauthorized disclosure underscore this policy" Cooper v. Hallgarten \& Co., 34 F.R.D. at 483 (emphasis added).

67. Although Judge Weinfeld, in Cooper, did not cite or acknowledge Judge Bryan's earher opinion in Kingsley for the saine court, he chose the saine term, "underscore," to express the relation between the policy of nondisclosure and the statutory criminal sanctions. See supra notes 65-66.

68. See, e.g., Sinith v. Bader, 83 F.R.D. 437, 438 (S.D.N.Y. 1979) (this "historic trend [away froin routine discovery of tax returns] seems to stem in part from the private nature of the sensitive information contained therein"); Wiesenberger v. W. E. Hutton \& Co., 35 F.R.D. at 557 ("People are normally opposed to the invasion of their privacy by exposure of the details contained in an 
cited as policy grounds for restricting discovery. Taxpayer privacy seeins to be the more compelling of the two considerations. Rule $26(c)(7)$ specifically provides for a protective order in order "that a trade secret or other confidential . . . commercial information not be disclosed or be disclosed only in a designated way."70 Where personal privacy interests are unjustifiably threatened, however, Rule 26 does not specify what kind of protective order nay be available. Because of the particularity with which Rule 26 treats business secrets, there is less need for an independent "qualified" discovery privilege to protect them..$^{71}$ This note will examine the policy of taxpayer privacy in greater detail. ${ }^{72}$

In Federal Savings and Loan Insurance Co. v. Kreuger, ${ }^{73}$ the court advanced another basis for limiting discovery: a policy "grounded in the interest of the government in full disclosure of all the taxpayer's incoune which thereby inaximizes revenue."74 The court in Payne $v$. Howard ${ }^{75}$ adopted the dual pohicy basis of naximizing revenue and encouraging taxpayers' use of "all of the tax-saving measures to which they are lawfully entitled."76 Still other cases speak of a public interest in promoting the filing of "coinplete and accurate" returns. ${ }^{77}$ This note will examme these policies im greater detail. ${ }^{78}$

incoine tax return."). But cf. Heathman v. United States Dist. Court, 503 F.2d 1032, 1035 (9th Cir. 1974) ("Defendants also argue that the discovery of their copies of their tax returns violates their right of privacy and their right to be free from unreasonable searches and seizures. . . . There is no inerit in these constitutional claims.").

69. In Premiun Serv. Corp. v. Sperry \& Hutchinson Co., 511 F.2d 225 (9th Cir. 1975), the Ninth Circuit upheld the quashing of a subpoena of third-party tax returns in an antitrust suit. Although the court adduced other grounds, the opinion suggests that it might equally have sustained the quashing for privacy reasons: "The district court could reasonably have found, without abusing its discretion, that [the plaintif's] need for these documents was not sufficient to outweigh the burden and invasion of corporate privacy which would have resulted to [the third parties], especially since they were not parties to the suit." Id. at 229 (emphasis added). In Richland Wholesale Liquors, Inc. v. Joseph E. Seagrain \& Sons, 40 F.R.D. 480, 482 (D.S.C. 1966), another antitrust action, the court equated the discovery of tax returns to "giving a coinpetitor entree into [an adversary's] business."

70. FED. R. CIV. P. 26(c)(7).

71. The Supreme Court has acknowledged that Rule 26(c)(7) accords trade secrets what amounts to a "qualified" privilege against discovery. Federal Open Mkt. Comm. v. Merrill, 443 U.S. 340,356 (1979).

72. See infra notes $120-39$ and accompanying text.

73. 55 F.R.D. 512 (N.D. Ill. 1972).

74. Id. at 514.

75. 75 F.R.D. 465 (D.D.C. 1977).

76. Id. at 469.

77. See, e.g., Prenium Serv. Co. v. Sperry \& Hutchinson Co., 511 F.2d 225, 229 (9th Cir. 1975) ("coinplete and accurate" returns are needed for tax laws to function properly); Smith v. Bader, 83 F.R.D. 437, 438 (S.D.N.Y. 1979) (reluctance to order routine discovery of tax returns stems in part from the public interest in filing "complete and accurate returns").

78. See infra notes $112-19$ and accompanying text. 


\section{The Wisdom and Necessity of the "Qualified" TaX Return Privilege}

\section{A. The New Law of "Qualified" Privileges.}

In 1975, Congress rejected an exclusive list of evidentiary privileges proposed by the Supreme Court, and enacted instead the openended language of Rule 501:

Except as otherwise required by the Constitution of the United States or provided by Act of Congress . . . the privileges of a witness [or] person shall be governed by the principles of the common law as they nay be interpreted by courts of the United States in the hight of reason and experience. ${ }^{79}$

Most authorities view Rule 501 as a congressional endorsement of further case-by-case development of the federal common law of privilege. ${ }^{80}$ Because the concept of "privilege" in the Federal Rules of Civil Procedure is drawn from the law of evidence, ${ }^{81}$ there is support for the view that Congress has implicitly endorsed a parallel evolution in the law of pretrial discovery. ${ }^{82}$

In recent years, federal courts have begun to recognize various claims of "qualified" privilege. The label itself is uninformative and perhaps misleading, for the issue before these courts lias been what might better be termed a conditional immunity from discovery-no court has indicated that a "qualified" privilege could be invoked at the trial. ${ }^{83}$ Nevertheless, courts have found the term "qualified" privilege

79. FED. R. Evid. 501.

80. See, e.g., Trammel v. United States, 445 U.S. 40, 47 (1980); see also M. GRAHAM, HANDBOOK OF FEDERAL EVIDENCE 295 (1981).

81. According to FED. R. EvID. 1101(c), "[t]lhe rule with respect to privileges applies at all stages of all actions, cases, and proceedings." Therefore an evidentiary privilege is also a privilege against discovery. That the converse is true is shown by the opinion in United States v. Reynolds, 345 U.S. I, 6 (1953) ("[w]e think it should be clear that the term 'not privileged,' as it is used in Rule 34, refers to 'privileges' as that term is understood in the law of evidence."). Given the linkage between discovery privilege and evidentiary privilege, it is understandable that courts ready to deny discovery of tax returns state that no "absolute" privilege exists. See, e.g., Eastern Auto Distribs. v. Peugeot Motors of Am., 96 F.R.D. 147, I48 (E.D. Va. 1982) (noting that most courts recognize only a "qualified" privilege against disclosure of tax returns).

82. Cf. EEOC v. University of Notre Dame, 715 F.2d 331, 334-35 (7th Cir. 1983) (discusses congressional pohcy behind Rule 501 before turning to discussion of claim that academic personnel files are subject to "qualified" discovery privilege).

83. Cf. Kirkland v. Morton Salt Co., 46 F.R.D. 28, 30 (N.D. Ga. 1968) (the rule of Hickman v. Taylor created a "qualified immunity rather than a privilege" against discovery of a lawyer's work product); City of Philadelphia v. Westinghouse Elec. Corp., 210 F. Supp. 483, 485 (E.D. Pa. 1962) (the "work product" rule does not create a qualified privilege but is rather a requirement that the party seeking discovery show "very good cause"). See generally 8 C. WriaHT \& A. MILLER, supra note $50, \S 2025$ at $210-28$. 
apt and have made a place for it in federal jurisprudence. ${ }^{84}$

The law of "qualified" privileges is new, tentative, and ill-defined. The most significant federal case to establish a "qualified" privilege was Hickman v. Taylor. ${ }^{85}$ In that case, the Supreme Court held that an attorney enjoys a limited privilege in a given suit with respect to his "work product" prepared for the litigation of that suit. 86 One of the underlying bases for the Court's holding was a recognition that free access to an adversary attorney's files would encourage litigants to defer preparation of their own cases, in the expectation of being able imexpensively to take advantage of their adversaries' product in preparation for trial. ${ }^{87}$ The rule of Hickman v. Taylor demes discovery of an adversary's "work product" except upon a showing of need and inability to obtam the information from other sources. ${ }^{88}$ The Court carefully distinguished this protection of attorney work-product from the common law attorney-client privilege. ${ }^{89}$

Simce Hickman v. Taylor, federal courts liave recognized other claims of "qualified" privilege. Several circuits have agreed that newsgatherers enjoy a "qualified" privilege agamst discovery of the identities of their confidential news sources. 90 Other courts have recognized a "qualified" privilege limiting discovery of grand jury testimony in tangential proceedings.91 Still other courts have approved a "qualified" privilege protectimg academic "peer review" voting on candidates

84. See, e.g., Federal Open Mkt. Comm. v. Merrill, 443 U.S. 340, 356 (1979) (Rule 26(c)(7) provides a "qualified privilege" for trade secrets); United States v. Nobles, 422 U.S. 225, 237-38 (1975) ("The privilege derived from the work product doctrine [may] . . . [1]ike other qualified privileges . . . be waived); In re Dinnan, 661 F.2d 426, 428 (5th Cir. 1981) ("[O]ther privileges .. . night be classified as qualified privileges [such as] the "work product privilege.' "), cert. denied, 457 U.S. 1106 (1982); Silkwood v. Kerr-McGee Corp., 563 F.2d 433, 435 (10th Cir. 1977) ("a qualified privilege is in the process of developing").

85. 329 U.S. 495 (1947).

86. Id. at 508-10.

87. Id. at 510-11; accord United States v. Nobles, 422 U.S. 225, 248 (1974) (White, J., concurring) ("the danger perceived in Hickman [was] that each party to a case will decline to prepare in the hopes of eventually using his adversary's preparation").

88. See Hickman, 329 U.S. at 509-11. In 1970, the rule of Hickman v. Taylor was incorporated into the federal discovery rules. Fed. R. Civ. P. 26(b)(3); 8 C. WRIGHT \& A. MiLlER, supra note $50, \S 2023$ at 193.

89. Hickman, 329 U.S. at 508.

90. See, e.g., In re Selcraig, 705 F.2d 789, 792 (5th Cir. 1983); Bruno \& Stillman, Inc. v. Globe Newspaper Co., 633 F.2d 583, 595-96 (1st Cir. 1980); Riley v. City of Chester, 612 F.2d 708, 715 (3d Cir. 1979); Silkwood v. Kerr-McGee Corp., 563 F.2d 433, 436-37 (10th Cir. 1977); Carey v. Hunne, 492 F.2d 631, 639 (D.C. Cir.), appeal dismissed, 417 U.S. 938 (1974); Garland v. Torre, 259 F.2d 545, 548-49 (2d Cir.), cert. denied, 358 U.S. 910 (1958).

91. See, e.g., Douglas Oil Co. v. Petrol Stops Northwest, 441 U.S. 211, 218-24 (1979) (grand jury transcripts discoverable only upou a showing of "particularized need" to avoid a "substantial injustice"); Lucas v. Turner, 725 F.2d 1095, 1109 (7th Cir. 1984) (terms Douglas rule a "qualified" discovery privilege). 
for tenure. 92

These "qualified" privileges evolving in federal courts appear to be characterized by two features: 1) once a source of information is shown to fall within a category subject to the "qualified" privilege, the opponent of discovery is deemed to have met his initial burden, under rule 26(c), of showing "good cause" why discovery should not be had; and, 2) information shown to fall within such a category is not discoverable until and unless the proponent of discovery can show: a) that the information sought is needed; b) that it is relevant to the case; and, c) that it is not reasonably available from alternative sources. ${ }^{93}$

Three remarks need to be made about the "quahified" privileges. First, the "qualified" privileges fit into the schema of the discovery rules not as privileges in the full-blown sense-for if they did, of course, they would be an insuperable barrier to discovery, absent waiver-but as devices relieving the opponent of the initial burden of showing "good cause."94 Second, although many courts have emphasized the "fact intensive" nature of the case-by-case development of the law of privilege, the "quahified" privilege effectively reheves the opponent of his initial burden, under Rule 26 , by showing that discovery would expose him to "annoyance, embarrassment, oppression, or undue burden or expense."95 Third, the showing of "need" and "rele-

92. See, e.g., EEOC v. University of Notre Dame, 715 F.2d 331, 337 (7th Cir. 1983); Gray v. Board of Higher Educ., 692 F.2d 901, 908 (2d Cir. 1982). Contra, In re Dinnan, 661 F.2d 426, 430 . 31 (5th Cir. 1981) (refusing to establish an evidentiary privilege to enable professor to withhold information on how he voted on plaintiffs promotion to associate professor), cert. denied, 457 U.S. 1106 (1982).

The terminology of "qualified" privilege has been used in other, more isolated cases. See, e.g., United States v. Green, 670 F.2d 1148, 1155 (D.C. Cir. 1981) ("qualified" privilege protecting police surveillance locations); Davis v. Braswell Motor Freight Lines, Inc., 363 F.2d 600, 604-05 (5th Cir. 1966) ("qualified" privilege protecting "intra-agency correspondence discussing the course of conduct to be followed by the parties [to an NLRB proceeding] and expressing opinions as to the merits of various claims").

93. See, e.g., Miller v. Transamerican Press, Inc., 621 F.2d 721, 725-26 (5th Cir. 1980) (newsnuan's confidential source discoverable by plaintiff only where such information is relevant, undiscoverable by other ineans, and there is a "coinpelling interest"), cert. denied, 450 U.S. 1041 (1981); EEOC v. University of Notre Dame, 715 F.2d 331, 338-39 (7th Cir. 1983) (identity of academic "peer reviewers" in tenure decision is discoverable by an employment discrimination plaintiff only upon a showing of "particularized need," i.e., that he has "conduct[ed a] thorough and exhaustive [search of alternative sources] prior to seeking those inaterials protected by the qualified privilege").

94. See EEOC v. University of Notre Dame, 715 F.2d 331, 338-39 (7th Cir. 1983) ("because we have held that the peer review nuaterials are subject to a qualified privilege, it necessarily follows that sufficient 'good cause' exists to protect these inaterials"); $c f$. Carr v. Monroe Mfg. Co., 431 F.2d 384, 389 (5th Cir. 1970) (where government asserts a novel privilege it should be considered "as part of the good cause requirenent [of Rule $26(\mathrm{c})$, presumably] by balancing competing policies.").

95. FED. R. CIV. P. 26(c). 
vance" to which the proponent of discovery is put seems to require a sharp joimder of issues between the parties. The federal rules, however, were initially imtended to perform an "issue shaping" function, which did not presuppose that the issues between the parties were set into final form. ${ }^{96}$ Moreover, many decisions have distimguished the notion of relevance that operates at trial from the looser notion of relevance that is imtended to govern the discovery stage. ${ }^{97}$ The point of these remarks has been to indicate precisely how the "qualified" privileges fit into the standard structure of the federal discovery rules and how they alter that structure. It should also be noted that the "qualified" tax return privilege expressed in the Cooper rule closely approximates the structure of the other "qualified" federal discovery privileges.

The question arises, wliether "qualified" discovery privileges are to be established on grounds differing in any way froin those upon which the traditional "absolute" privileges liave been raised. It could

96. See Hickman v. Taylor, 329 U.S. 495, 501 (1947) ("The various instruments of discovery serve . . . as a device . . . to narrow and clarify the basic issues between the parties, and . . . as a device for ascertaining . . . the existence or whereabouts of facts, relative to those issues."); FED. R. Civ. P. 8, 15(b); Pike \& Willis, The New Federal Deposition-Discovery Procedure I, 38 Colum. L. REv. 1179, 1179-80 (1938) ("The new federal rules of civil procedure . . . [reflect] the newer concept of 'notice pleading'; . . . what have been thought to be the objects of pleading-the narrowing of issues, the revelation of facts-will be served by several devices more precisely adapted to their fulfillment [imcluding] the . . . complctely renovated procedure for . . . discovery."). As the liberal amendment provisions of Rule 15(b) suggest, facts revealed in the discovery process will permit hitigants to press issues not otherwise apparent in the pleadings, and press them against persons not originally parties. See Bloomfield Mechanical Contracting, Inc. v. Occupational Safety \& Health Review Comm'n., 519 F.2d 1257, 1262 (1975) ("The purpose of the rule is to ameliorate the statute of limitation ... . where the [proper] party has had adequate notice of the institution of the action.").

97. Once an objection of irrelevance is raised, the burden shifts to the party seeking discovery to show that the matter sought is relevant to the subject matter of the litigation, but that burden is little more than one of showing that there is some possibility that the matter sought will lead to admissible evidence. United States v. International Business Mach., 66 F.R.D. 215,218 (S.D.N.Y. 1974). But of. Home Ins. Co. v. Ballenger Corp., 74 F.R.D. 93, 101 (N.D. Ga. 1977) ("A general allegation of relevancy is not sufficient to overcome specific objections by an adverse party."). The Advisory Committee has noted that

Since decisions as to relevance to the subject matter of the action are made for discovery purposes well in advance of trial, a flexible treatment of relevance is required and the making of discovery, whether voluntary or under court order, is not a concession or determination of relevance for purposes of trial.

FED. R. CIV. P. 26(b)(1) advisory committee notes (1966 amendments).

The cases distinguish trial "relevance" and discovery "relevance to the subject matter." See, e.g., McClaim v. Mack Trucks, Inc., 85 F.R.D. 53, 61 (E.D. Pa. 1979); FDIC v. Mercantile Nat'1 Bank of Chicago, 84 F.R.D. 345, 348 (N.D. Ill. 1979). Moreover, courts have endorsed a willingness to look beyond the pleadings to determine relevance to the subject matter of the litigation for discovery purposes. See, e.g., Duplan Corp. v. Decring Milliken, Inc., 397 F. Supp. 1146, 1187 (D.S.C. 1975) ("relevancy to the subject nuatter . . . is broader than relevancy to the issues presented by the pleadings"); Kaiser-Frazier Corp. v. Otis \& Co., 11 F.R.D. 50,53 (S.D.N.Y. 1951). 
be argued that a lesser form of privilege requires a lesser degree of justification, but to do so would be to slight the fact that privileges are "strongly disfavored"98 in federal practice: "Whatever their origin's [whether constitutional, statutory, or common law], these exceptions to the deinand for every inan's evidence are not lightly created nor expansively construed, for they are in derogation of the search for truth." 99

Not only is a "qualified" privilege an impediment to discovering the truth, but circumstances will arise in which it is as formidable an obstacle as an absolute privilege. Where a privileged document is a summary of what may be volumes of other inaterial, the process of exhausting the alternative sources may exhaust a hitigant's war chest as well. ${ }^{100}$ Cost factors aside, the "qualified" privileges deprive a litigant of first-hand information. Should he obtain a passable facsimile second hand, the party seeking discovery will be denied the first-hand version and whatever leads or impeachable discrepancies it may contain. ${ }^{101}$ "Qualified" privileges should be held to the same standard of justification as absolute ones because, as a practical inatter, there will be cases in which they have an equivalent effect upon the outcoine.

It might appear inconsistent to protect one category of evidence by an absolute privilege while another category, having satisfied the same standard, is protected by a mere "qualified" privilege. This inconsistency is dispelled once one realizes that the inquiry into the appropriateness of a special protection does not exhaust the further inquiry imto the proper extent of that protection. At common law, for exainple, there is both an "absolute" spousal privilege and an "absolute" attorney-client privilege. Nevertheless, the spousal privilege reaches all commumications between husband and wife, ${ }^{102}$ while only those commumications from client to attorney that arise from an actual or incipient representation are within the latter privilege. ${ }^{103}$ Common law courts were no inore irrational in creating sucl1 distinctions than federal courts have been in creating a special class of "qualified" privileges. It may be that federal courts have insisted upon the soinewhat improper

98. ACLU v. Finch, 638 F.2d 1336, 1345 (5th Cir. 1981).

99. United States v. Nixon, 418 U.S. 683, 710 (1973) (einphasis added).

100. An egregious example is seen in Eastern Auto Distribs., Inc. v. Peugeot Motors of Am., Inc., 96 F.R.D. 147 (E.D. Va. 1982), where the court referred the party seeking discovery of his opponent's tax return to several alternative sources, the remotest of which was the files of the French regulatory agency that oversees the operations of the Bourse. Id. at 149 n.1.

101. See Rubenstein v. Klein, 21 F.R.D. 183, 184 (D. Mass. 1957) (tax returns held discoverable for purposes of impeachment, where incoine is in issue).

102. See 8 J. WIGMORE, WIGMORE ON EVIDENCE $\& 2232$ at 225-26 (J. McNaughton cd. 1961).

103. Id. $\$ 2304$ at 586 ("[C]ommunications are protected, not merely when the person consulted is a professional legal adviser, but ouly when the person consulting is seeking the benefit of that relation."). 
terminology of privilege in these cases precisely because they do not wish to exempt the "qualified" privileges from the rigorous threshold justification traditionally required of privileges. 104

The courts that have created "qualified" privileges have not followed a uniform path of analysis. Some courts have employed a test balancing the policy interests served by limiting discovery against the interest favorimg the availability of "every man's evidence" in the adversarial searcli for truth. ${ }^{105}$ Other courts liave followed Wigmore's classic formulation, which inakes the existence of a confidential relation a predicate to the judicial creation of a privilege. ${ }^{106}$ Significant policies are at the root of both forms of analysis. Hickman v. Taylor and the "qualified" privilege of grand jury testimony rest upon a judicial concern for the protection of the integrity and functioning of the judicial process itself. 107 The qualified "reporter's confidential source" and "academic peer review" privileges rest upon a concern not to "chill" the exercise of well-established constitutional liberties. 108 A "qualified" tax return privilege should be created only for substantial reasons of coinparable weight.

\section{B. "Qualified" Privileges and Income Tax Returns.}

Many courts have been drawn to the idea of specially restricting discovery of federal income tax returns. The variety of rationales and outcomes found in the cases may suggest the early stages of the coinmon law evolution of another important procedural safeguard. This

104. Cf. Gray v. Board of Higher Educ., 692 F.2d 901,904 (2d Cir. 1982) (upholds the principle of a qualified "academic peer review" privilege, noting that "to sustain a privilege there inust be 'a public good transcending the nonnally predominant principle of utilizing all rational ineans for ascertaining the truth." (quoting Trammel v. United States, 445 U.S. 40, 50 (1980)).

105. See, e.g., Gray v. Board of Higher Educ., 692 F.2d 901, 904-0S (2d Cir. 1982) (in civil rights actions, court employs balancing test in resolving tension between need for disclosure in employment discrimination and need for confidentiality in academic tenure decisions).

106. See, e.g., Zaustinsky v. University of Cal., 96 F.R.D. 622, 624-25 (N.D. Cal. 1983) (qualified "academic peer review" privilege apphed); 8 J. WIGMORE, supra note 102, § 2285 at 527-28.

107. See Hickman v. Taylor, 329 U.S. 495, 511-12 (1946) (policy underlying "work product" rule is "essential to an orderly working of our systein of legal procedure"); United States v. Sells Eng'g., Inc., 103 S. Ct. 3133, 3138 (1983) ("We have consistently recognized that the proper functioning of our grand jury system depends upon the secrecy of the grand jury proceedings." " (quoting Douglas Oil Co. v. Petrol Stops Northwest, 441 U.S. 211, 218-19 (1979)); see also U.S. CoNST, amend. VI (guarantees grand jury presentment prior to federal criminal prosecution).

108. See Regents of the Univ. of Cal. v. Bakke, 438 U.S. 265, 312 (1978) (opimion of Powell, J.) ("Academic freedoin, though not a specifically enumerated constitutional right, long has been viewed as a special concern of the First Amendinent.") quoted in In re Dinnan, 661 F.2d 426, 430 (5th Cir. 1981) (rejecting claim of qualified "academic peer review" privilege), cert. denied, 457 U.S. 1106 (1982); Miller v. Transamerican Press, Inc., 621 F.2d 721, 725 (5th Cir. 1980) ("A reporter has a First Amendment privilege which protects the refusal to disclose the identity of confidential informants; however, the privilege is not absolute."), cert. denied, 405 U.S. 1041 (1981). 
variety ${ }^{109}$ may also suggest, however, that a fundamental assumption of the cases-the necessity of a tax return privilege granting more protection than the federal discovery rules-is imcorrect.

Rule 26(c) provides that the court may, upon a showing of good cause by the opponent of discovery, "make any order which justice requires to protect a party or person from annoyance, embarrassment, oppression or undue burden or expense."110 Burdening the opponent of discovery to show good cause why a protective order should issue is consistent with the "broad and hiberal treatment" accorded the federal discovery rules. 111

The remamder of this note will review the policies advanced in support of the "qualified" privilege doctrine as applied to tax returns. Because courts have demonstrated an ability to fashion safeguards under Rule 26(c) to protect the taxpayer from unnecessary discovery of returns, the presumption is that, unless an overriding policy concern exists, federal income tax returns are to be treated in the same way as other financial documents and that motions to compel or to limit their discovery should be treated according to the standard structure laid down in Rules 34 and 26.

1. Taxpayer Compliance. Taxpayer compliance is the central concern of most pohicies advanced today to support the "qualified" tax

109. Widely divergent results can be derived from a given factual setting under the Cooper and the Kingsley rules. See generally supra notes 39-53 and accompanying text. Under Kingsley the focus of mquiry is who, if anyone, raised the issue of income. Under Cooper the focus is upon relevance and availability from other sources.

The cases that invoke both Kingsley and Cooper guidelines for analysis apply them either in the alternative, e.g., Payne v. Howard, 75 F.R.D. 465 , 470 (D.D.C. 1977); see supra notes 75-76 and accompanying text; or engage in a balancing of factors drawn from the two, e.g., Smith v. Bader, 83 F.R.D. 437, 438-39 (S.D.N.Y. 1979). Thus far, the fact patterns tested under the "alternative" approach would have yielded an identical result under Cooper and Kingsley. The results of the "balancing" approach are difficult to characterize, but whenever the party resisting discovery seems even remotely to have tendered the issue of his income, discovery is allowed. See, e.g., Bader, 83 F.R.D. at 438-39 (plaintiffs deemed to have placed their mcome in issue by claiming that they suffered a loss due to the defendants' alleged securities violations); Mitsui $\&$ Co. v. Puerto Rico Water Resources, 79 F.R.D. 72, 81 (D.P.R. 1978) (plaintiffs place income in issue by claiming losses for alleged breach of contract).

110. FED. R. CIv. P. 26(c). Where an objection to discovery has been raised, some courts have ordered production but kept the tax return under seal. Credit Life Ins. Co. v. Uniworld Ins. Co., 94 F.R.D. 113, 121 (S.D. Ohio 1982); Weiner v. Bache Halsey Stuart, Inc., 76 F.R.D. 624, 627 (S.D. Fla. 1977). Another court has found privacy concerns satisfied by the discovering party's offer to stipulate to an order of confidentiality. Smith v. Bader, 83 F.R.D. 437,439 (S.D.N.Y. 1979). Still another court has limited production to specific portions of the tax return. See Taylor v. Atchison T. \& S.F. Ry. Co., 33 F.R.D. 283, 286 (W.D. Mo. 1962); Developments in the Law, supra note 43, at 1011-12.

111. Hickman v. Taylor, 329 U.S. 495, 507 (1947). 
return privilege.112 The success of our "self-assessment" system of taxation depends upon a high degree of voluntary taxpayer compliance and some courts fear that "routime" discovery of tax return information will discourage complete disclosure.

Courts invoking the policy of fostering compliance seldoin treat it as an end in itself. Taxpayer filing of complete and accurate returns is important because it is instrumental to the further policy goal of maximizing federal revenue. ${ }^{113}$ One court has identified an independent policy goal favoring the use by taxpayers of all the deductions to which they are entitled. ${ }^{114}$ Recent cases, however, have singled out the interest in the filing of complete and accurate returns of losses and deductions as not warranting a restriction of discovery of tax returns. ${ }^{115}$ These cases rest upon the commonsense notion that a taxpayer has a sufficiently great incentive, derived from the prospect of tax savings, to report fully his "tax losses and tax shelters." 116 This incentive exists wholly apart from any expectation that tax infornation will be exempted from discovery in civil litigation.

Most courts recently endorsing the "qualified" privilege have been guided by the argument that "routine" discovery of tax returns in private civil litigation will have the effect of impairing the collection of federal revenues. This reasoning is not consistent with the federal judiciary's typical deference to Congress where revenue policy is at issue ${ }^{117}$

112. See infra note 126; see also Tele-Radio Sys., Ltd. v. DeForest Elecs., Inc., 92 F.R.D. 371, 375 (D.N.J. 1981) (" 'Public policy against unnecessary public disclosure arises from the need . . . to encourage taxpayers to file complete and aceurate returns." (quoting Premium Serv. Co. v. Sperry \& Hutchinson Co., 511 F.2d 225, 229 (9th Cir. 1975)); Smith v. Bader, 83 F.R.D. 437, 438 (S.D.N.Y. 1979) ("public interest in encouraging the filing by taxpayers of coinplete and accurate returns"); Houlihan v. Anderson-Stokes, Inc., 78 F.R.D. 232, 234 (D.D.C. 1978) ("the fear of public disclosure might . . . hinder the 'full disclosure of all the taxpayer's income whicls thereby maximizes revenue," " (quoting Federal Sav. \& Loan Ins. Corp. v. Krueger, 55 F.R.D. 512, 514 (N.D. Ill. 1972)); Payne v. Howard, 75 F.R.D. 465,469 (D.D.C. 1977) (without assurance of confidentiality, reporting of all taxable incone will be discouraged); Federal Sav. \& Loan Ins. Co. v. Kreuger, 55 F.R.D. 512, 514 (N.D. I11. 1972) (full disclosure is furthered by a policy of confidentiality).

113. See supra note 112; infra note 137.

114. Payne v. Howard, 75 F.R.D. 465,469 (D.D.C. 1977).

115. Smith v. Bader, 83 F.R.D. at 439; Houlihan v. Anderson-Stokes, Inc., 78 F.R.D. 232, 234 (D.D.C. 1978).

116. Smith v. Bader, 83 F.R.D. at 439; Houlihan v. Anderson-Stokes, Inc., 78 F.R.D. 232,234 (D.D.C. 1978).

117. See Umited States v. Arthur Young \& Co., 104 S. Ct. 1495, 1505 (1984) (reversing the Second Circuit, which had created a "qualified" privilege for tax accrual workpapers: "This kind of policy choice [involving balancing of competing interests] is best left to the Legislative Brancl.."); United States v. Correll, 389 U.S. 299, 306-07 (1967) ("[W]e do not sit as a committee of revision to perfect the administration of the tax laws. Congress has delegated to the Commissioner, not to the courts, the task of prescribing 'all needful rules and regulations for the enforceinent' of the . . . Code." (citation omitted)); United States v. Noall, 587 F.2d 123, 126 (2d Cir. 
and it is vulnerable to another very strong-if obvious—objection. A great deal of income information is supplied to the government both by the taxpayer and by the incoine source, e.g., an employer or a financial institution. ${ }^{118}$ It is unlikely that the distant prospect of civil discovery will influence a reasonable taxpayer to withhold from the government income information it will routmely receive from another source. Full taxpayer reporting of income from tips or rent, which is not reported to the government by its source, could conceivably be compromised. The likehhood of this is minimal, however, because the benefit of not having to disclose tax return information if a civil suit materializes hardly seems to outweigh the risks inherent in violating the tax laws. ${ }^{119}$ Even if revenue maximizing were a proper and significant judicial concern,

1978) ("These cases [finding a 'self-evaluative report' privilege] arose in the course of discovery where the Rules of Civil Procedure leave inuch to the judge's discretion. With respect to enforcement of the tax laws, Congress itself has decided the policy issue, and it is not for the courts to challenge that determination. In this, as in inany other procedural questions, the collection of revenue stands apart." (citing Murray's Lessee v. Hoborow Land \& Inprovement Co., 59 U.S. (18 How.) 272, 282 (1856))). But see United States v. Brown, 478 F.2d 1038, 1040-41 (7th Cir. 1973) ("work product" doctrine held applicable to a proceeding for enforcement of an IRS summons).

118. According to the Commissioner of Internal Revenue, the IRS annually collects two billion dollars in taxes on unreported income by "matching" third-party reports on such items as wages, interest, dividends, securities and retirement account transactions with the taxpayers' itemized returns "or the lack of returns." Wall St. J., Sept. 12, 1984, at 1, col. 5.

119. See Developments in the Law, supra note 43, at 1010-12. "Chilling effect" arguments have been made in recent cases touching upon othcr areas of tax admimistration. In United States v. King, 73 F.R.D. 103, 104 (E.D.N.Y. 1976) (Weinstein, J.), the City of New York, arguing privilege, moved to quash a subpoena that had been issued for the original city tax return of the defendant in a criminal tax fraud prosecution. The court's inquiry concerned the "chilling" effect upon income reporting that the city alleged would result if the court subscribed to a policy of enforcing such subpoenas. The court found that the confidentiahity provisions of the city income tax statute represented a "relatively weak policy" in that the statute provided for reciprocal exchanges of imdividual tax return information with other taxing authorities for purposes of tax enforcement. Id. at 108 . The court wrote:

Honest reporting by city taxpayers is induced chiefly by reliance on criminal statutes, cooperation with other taxing authorities and techniques for withholding taxes at the source as well as by other devices. We take judicial notice that such prograins are iinmeasurably more effective than are privilege provisions as means to the ends sought by the City. The privilege is relied upon only as a peripheral inducement to voluntary declaration of tax liability to the City.

Id. (citation omitted). The court found that a balancing of factors favored enforcement of the subpoena, in that the "nost powerful and least variable" of the factors-the need to put all relevant evidence before the trier of fact-clearly outweighed what was "at most, an imsignificant adverse impact upon a state policy that is, at best, marginally served by the local statutory scheine of limited confidentiality." Id. at 105, 109. The motion to quash was accordingly denied.

The King analysis has been criticized. See In re Cruz, 561 F. Supp. 1042, 1043-45 (D. Conn. 1983). There, the court ordered the quashing of a subpoena of state tax files issued by a federal grand jury. King was distinguished on the ground that it had preceded the passage of the 1976 Tax Reform Act, and that I.R.C. $\$ 6103(i)(I)$, as amended, controlled the procedures for subpoena of tax returns in nontax criminal investigations. Id. at 1044-45. The court, reasoning by analogy, held that the procedures set out in $\$ 6103(i)(1)$ control equally where a federal grand jury seeks to subpoena state imcone tax returns. Id. at 1045-46. 
there is no reason that the protective devices of Rule 26 should be less effective in service of that concern than a "qualified" discovery privilege.

\section{Privacy and Confidentiality. In Heathman v. United States} District Court, ${ }^{120}$ the Ninth Circuit held that the taxpayer's interest in the privacy of his federal return was not within the protection of the Constitution. The court found "no merit" in the defendants' contention that discovery of their federal tax returns would violate their constitutional right to privacy or their fourth amendinent right to be free from unreasonable searches and seizures. ${ }^{121}$ The absence of a constitutional basis, however, does not inean that the taxpayer's privacy interest is negligible or unworthy of judicial concern, ${ }^{122}$ although it is not

The provisions of I.R.C. $\$ 6103(i)(1)$, which pertain to nontax criminal investigations, require government prosecutors to make a showing of need before an ex parte subpoena will issue. The showing required is that:

(i) there is reasonable cause to beheve . . that a specific criminal act has been committed; (ii) there is reason to beheve that such return or return information is probative evidence [regarding] . . . the criminal act; and (iii) the information sought to be disclosed cannot reasonably be obtained from any other source, unless. . . [it] constitutes the most probative evidence of a matter in issue relating to . . . such criminal act.

I.R.C. $\$ 6103(\mathrm{i})(1)(\mathrm{B})(\mathrm{i})$-(iii) (1982) (einphasis added).

A comparison between this provision and the "qualified" tax return privilege in civil discovery is imstructive. The provision parallels the structure of the new "quahified" privileges, except that it provides for subpoena where the tax return is the most probative evidence on a matter in issue, and in such circumstances the subpoena will issue whether or not the information is otherwise available. Therefore, the $\$ 6103(\mathrm{i})(1)(B)$ provision is significantly less restrictive than its judicially created counterpart, the Cooper rule. A pubhe pohcy favoring crime control might arguably justify this asymmetry. Yet, on the other hand, the ex parte uature of the procedure governed by $\$ 6103(i)(1)(B)$, and the fact that few private litigants enjoy the tremendous resources of the state, argue for allowing the private litigant grcater freedoin of discovery in order to prepare his case.

In the case of United States v. Arthur Young \& Co., 677 F.2d 211 (2d Cir. 1982), rev'd in pertinent part, 104 S. C. 1495, 1502-05 (1984), the Second Circuit created a Hickman v. Taylorstyle work-product privilege for tax accrual workpapers supphed by a client to his accountant for the purpose of preparing filings to comply with federal securities laws. The Second Circuit relied heavily upon a "chilling effect" rationale. Had it been upheld, Arthur Young would have been a departure from a considerable body of precedent holding that no accountant-client privilege exists in federal courts, Couch v. United States, 409 U.S. 322, 335 (1973), except in diversity cases where substantive state law applies such a privilege, e.g., Palmer v. Fislier, 228 F.2d 603, 608 (7th Cir. 1955). The Supreine Court reversed, lowever, opining that balancing the goal of fair and honest securities markets against the "chilling effect" of IRS subpoena power was a matter for congressional decision. United States v. Arthur Young, 104 S. Ct. 1495, 1502, 1505 (1984).

120. 503 F.2d 1032, 1035 (9th Cir. 1974) (relying upon Couch v. United States, 409 U.S. 322, 335-36 (1973) (holding that there is "no semblance of governmental compulsion" where IRS seeks to enforce a subpoena of tax-related documents in the possession of the taxpayer's accountant)).

121. Heathman, 503 F.2d at 1035.

122. The Advisory Committee noted that "a party's income tax return is generally held not privileged . . . and yet courts have recognized that interests im privacy may call for a measure of extra protection." FaD. R. CIv. P. 26(b) advisory committee note (1970 amendment) (citing Wiesenberger v. W.E. Hutton \& Co., 35 F.R.D. 566 (S.D.N.Y. 1964)). 
clear why this interest is of greater concern than the taxpayer's privacy interest in other financial documents that contam equivalent imformation. ${ }^{123}$ In many of the cases that accord tax returns a "qualified" privilege, the court has encouraged the party seeking discovery to locate the information he desires among other financial documents available from his adversary. ${ }^{124}$ This approach does not seem to be internally consistent if the privacy interest inheres in the information itself, rather than in the form in which that information is recorded.

It could be argued that there is an important difference between data that an imdividual voluntarily collects for his own reasons and data that an individual is forced to collect, transcribe, and file with the government under threat of civil and criminal penalties. The difference is that in the latter case, unlike the former, there is a degree of governmental intrusion that is in itself offensive to privacy whether or not the data is later disclosed. This aggravated intrusion, therefore, justifies special treatment of the tax return. But this argument would successfully distinguish discovery of tax returns from disrovery of equivalent information not filed on a tax return only if the imposition of a legal duty to file a tax return were itself an invasion of legitimate privacy rights. No court has shown such extreme deference to privacy imterests, ${ }^{125}$ lowever, even where the privilege agamst self-incrimination has

123. Judge Aldrich, ruling on a motion to compel production of tax returns, wrote:

If the plaintiff had a complete set of books and records which showed the figures that went into his returns, no one would say that he could not be ordered to produce them. The same information does not, unless the statute is very explicit, become any the less obtainable just because the plaintiff has written it down on a governmental form.

Tollefsen v. Phillips, 16 F.R.D. 348, 349 (D. Mass. 1954).

124. See, e.g., Eastern Auto Distribs., Inc. v. Peugeot Motors of Am., 96 F.R.D. 147, 149 \& n.I (E.D. Va. 1982) (periodic reports filed with the Commission des Operations de Bourse; official French commercial newspapers; opponent's annual reports); Tele-Radio Sys., Ltd. v. DeForest Elecs., Inc., 92 F.R.D. 371,374 n.1, 375 (D.N.J. 1981) (corporate minute book, stock book, stock transfer ledger, year-end financial statements, purchase orders, imvoices, acknowledgments, slipping documents, warranty documents, payment records, sales ledgers, bills of materials, "and the like"); $c f$. United States v. Biscegha, 420 U.S. 141, 146 (1975) ("Although sucl imvestigations [under IRS's § 7602 subpoena power] unquestionably involve some invasion of privacy, . . . the alternatives could well involve far less agreeable invasions of house, business, and records.").

125. The constitutional right of privacy exists in the "emanations" of the "penumbra" surrounding the first, third, fourth, fifth and ninth amendments. Griswold v. Connecticut, 381 U.S. 479,484 (1965). Of the provisions of the Bill of Rights, only the fourth and fifth ainendinents appear to have been urged as grounds for restricting access by legal process to tax return information. See supra note 121 and accompanymg text; infra note 126 and accompanying text.

Although the states that have enacted an incoine tax have, without exception, made some provision for the confidentiality of tax return information, sucls provisions lave been lield not to derogate the reach of the subpoena power of federal courts in criminal cases. See United States v. King, 73 F.R.D. 103, 109 (E.D.N.Y. 1976) (city confidentiality statute lield not to insulate state tax returns from subpoena by federal prosecutor). See generally Note, Raiding the Confessional-The Use of Income Tax Rcturns in Nontax Criminal Investigations, 48 FordHAM L. REV. 1251, 1252 \& 
been implicated. 126

Anotlier dimension of the right of privacy lias to do with confidential relationships, e.g., with a minister, a physician, a legal counselor, a spouse. To tlie extent that our legal system values and seeks to foster such relationships, the communications essential to the development of these relationships are privileged in both the law of discovery ${ }^{127}$ and of evidence. ${ }^{128}$ The protection of certam confidential relationships has in fact been the keynote of privilege law. In Wigmore's classic formulation, a privilege slould be recognized only where the following four conditions are met:

(1) the communications nust originate in a confidence that they will not be disclosed;

(2) the elenent of confidentiality must be essential to the full and satisfactory naintenance of the relation between the parties;

(3) the relation must be one which in the opinion of the community ought to be sedulously fostered; and

(4) the injury that would mure to the relation by the disclosure of the communications inust be greater than the benefit thereby gained for the correct disposal of litigation. ${ }^{129}$

The relation between taxpayer and tax collector does not appear to satisfy Wigmore's first condition. A taxpayer's communications with the IRS arise from a legal duty to report income. ${ }^{130}$ A taxpayer has no assurance that his tax return will not be passed to anotlier agency of the federal government ${ }^{131}$ or of a state ${ }^{132}$ to be used to investigate his possible civil or criminal liability under tax or nontax law, and of course lie has no assurance that his tax return will not be used against him in court by a governmental adversary. ${ }^{133}$ The circulation of the tax return

n.11 (1980). But cf. FED. R. EviD. 501 (providing that state privilege law will prevail in civil diversity cases, with respect to issues for which state law provides the "rule of decision").

126. Compare United States v. Sullivan, 274 U.S. 259, 263 (1927) ("If the form of return provided called for answers that the defendant was privileged fron making he could have raised them on the return, but could not on that account refuse to make any return at all."), with Marchetti v. United States, 390 U.S. 39, 48-49 (1967) (holding that the fifth amendment excused professional gambler from filing an occupational tax return, every portion of which, unlike the mcome tax return in question in United States $v$. Sullivan, "had the direct and unmistakable consequence of incriminating petitioner"). The cases agree that the factor that triggers the privilege against self-imcrimination is not the degree of sensitivity of the information required by the Tax Code, but rather it is the reasonable likelihood that disclosure will result in a criminal penalty. See Unitcd States v. Doe, 104 S. Ct. 1237, 1241 n.8 (1984) (no "zone of privacy" protects personal papers absent a showing of compulsion).

127. See D. Louisell \& C. Mueller, Federal Evidence $\$ \S 200-02$ (1978).

128. See 8 J. WIGMORE, supra note $102, \S 2285$ at 527-28.

129. Id. (emphasis in original).

130. I.R.C. $\S \S 6651,7201-7207$ (1982).

131. I.R.C. $\$ 6103(\mathrm{~h})(2)(A)(1982)$. See generally Benedict \& Lupert, supra note 6, at 952-77.

132. I.R.C. $\S 6103$ (d) (1982). See generally Benedict \& Lupert, supra note 6, at 970-77.

133. I.R.C. $\S 6103(\mathrm{~h})$-(i) (1982). 
through these channels is not subject to the taxpayer's disapproval, and the bureaus that come imto possession of the information may well be legal adversaries of the taxpayer. Therefore, it is impossible to maintain that the filing of a tax return is a communication that origmates in a confidence that the information on the return will not be disclosed. In Lord Eldon's phrase, "[t]he moment confidence ceases, privilege ceases."134 The taxpayer will of course not expect his tax return to be grossly abused, but this expectation of confidentiahty is not markedly greater than that which resides in dozens of kinds of everyday relationships that have never been candidates for privileged status. ${ }^{135}$

Wigmore's second and fourth conditions both call for an assessment of the typical consequences of disclosure. The second condition requires that confidentiality "be essential to the full and satisfactory mamtenance" of the relationship in question. A showing of "essentiality" presumably would consist im a showing that damage to the relation would result from the relaxation of confidentiality, i.e., from disclosure. The fourth condition calls for a balancing of the resultant injury to the relation from disclosure agamst the good which disclosure would work in advancing the interests of justice. Because balancing calls for at least a rough assessment of the harm disclosure would do to the relation, both the second and the fourth Wigmore conditions call for the proponent of a privilege to show that the denial of the privilege would diminish confidentiality im such a way as to damage the relation. Because privileges are "not lightly [to be] created," 136 the proponent of the privilege should also show that this dainage is appreciable in degree. The question arises, how to measure the degree of damage to the taxpayertax collector relation? The cases ${ }^{137}$ strongly suggest that the proper

134. Pankhurst v. Lowten, 36 Eng. Rep. 59, 2 Swans. 194, 216 (1819); see United States v. Davis, 636 F.2d 1028, 1044 (5th Cir. 1981) ("federal and state tax returns and other reports filed with the government ... are not confidential communications and hence are not privileged" under attorney-chent privilege); see also Colton v. United States, 306 F.2d 633, 637-38 (2d Cir. 1962), cert. denied, 371 U.S. 951 (1963) ("a good deal of information transmitted to an attorney by a chent is not intended to be confidential, but rather is given for transunittal by the attorney to others-for inclusion in the tax return. Such information is, of course, . . . not privileged.").

135. No one would expect his disclosures to a lending institution, made in support of a loan application, to be publicized without his permission. Nevcrtheless, the borrower/lender relation does not come within any recognized privilege.

136. United States v. Nixon, 418 U.S. 683,710 (1973).

137. See, e.g., Premiun Serv. Corp. v. Sperry \& Hutchinson Co., 511 F.2d 225, 229 (9th Cir. 1975) ("A public policy against unnecessary public disclosure arises froun the need, if the tax laws are to function properly, to encourage taxpayers to file complete and accurate returns."); Heathman v. United States Dist. Ct., 503 F.2d 1032, 1036 (9th Cir. 1974) (Chainbers, J., concurring and dissenting) ("Because of our system of taxation through self-assessment, the unaximization of federal revenue hinges on complete and detailed reporting by each taxpayer. Such reporting is in a large part nourished by the confidential nature of the tax returns."). 
measure is the degree of voluntary taxpayer compliance with the tax laws. The effect of the threat of disclosure of tax return information in private nontax civil litigation upon taxpayer compliance was examined in the preceding section. If the conclusion reached there, that the effect is de minimis, is correct, then the "qualified" privilege also fails to satisfy either the second or the fourth of Wigmore's conditions.

It is inore difficult to say whether the taxpayer-tax collector relation satisfies Wigmore's third condition. The traditionally privileged relations-attorney-client, husband-wife, physician-patient-are typically personal, face-to-face relationships in which one party entrusts the protection of his interests to the other. Some courts have been reluctant to extend a privilege to relationships that are indirect or fleeting. ${ }^{138}$ Other courts, however, have regarded "encouraging the voluntary filing of certain records" as on a par with "fostermg relationships" for purposes of applying Wigmore's third condition. ${ }^{139}$ The relation between taxpayer and tax collector is typically impersonal and, where personal, it is adversarial. Although this fact may not entirely remove the taxpayer-tax collector relation from the scope of the traditional privileges, it does distinguish that relation from the paradigin examples.

\section{Conclusion}

More than forty years have passed since a federal court first denied discovery of a tax return on grounds of privilege. Yet subsequent decisions have sharply divided on the issue of the existence of even a "qualified" form of privilege, and the courts that have upheld the "quahified" privilege have not succeeded in reducing it to a univocal rule. Scant support for the "qualified" privilege doctrime is to be found in the tax code, the treasury regulations, the Constitution, or the common law.

As their designation suggests, the federal discovery rules are intended to expedite the searcli for truth. The implementation of the discovery rules necessarily affects other policy concerns, and where these other concerns are of overriding strength, the discovery rules inust

138. See In re Doe, 711 F.2d 1187, 1193 (2d Cir. 1983) (no psychotherapist-patient privilege because Wigmore's third condition not satisfied; "hardly any relationship of trust" arose due to this specific psychotherapist's “assembly-line technique”); FTC v. St. Regis Paper Co., 304 F.2d 731, 734 (7th Cir. 1962) ("We are not persuaded that the relationships between several members of a trade association and the association accountant should be considered a relationship equally valued, for the same reason, as the personal relationship between husband and wife, priest and penitant, [or] physician and patient.").

139. In re Grand Jury Impaneled Jan. 21, 1975, 541 F.2d 373, 382 (3d Cir. 1976). Wigmore himself brought the "informer's" privilege within his general analysis. $8 \mathrm{~J}$. WIGMORE, supra note $102, \S 2285$ at 528 . 
yield. Even so, the discovery rules have built into their structure a mechanism to protect litigants agamst the most common forms of discovery abuse. This structure places the burden of persuasion upon the opponent of discovery - he must show that "good cause" exists for the court to protect him agamst embarrassment or harassment. Federal courts should abandon this structure only grudgingly. The adoption of a "qualified" discovery privilege shifts the burden of persuasion onto the party seeking discovery. A "qualified" discovery privilege is a deviation from the standard structure of pretrial discovery that can be justified only by reference to policy concerns that the standard structure fails to satisfy.

Two policy concerns lie at the core of the decisions favoring a "qualified" tax return privilege. The first, privacy, does not justify preferential treatment of tax returns as agamst other documents bearing equivalent information, but no court has extended a "qualified" privilege to any financial document other than the tax return itself. Moreover, the "qualified" tax return privilege fails to satisfy Wigmore's prerequisites to the extra-statutory creation of a privilege. The second policy ground, here called "revenue maximizing," has become the major underpinning of the "qualified" privilege doctrine. The "revenue maximizing" rationale is not persuasive, however, because the impact of discovery conducted within the standard structure upon taxpayer comphance is speculative and would be minimal if actual. In addition, the "revenue maximizmg" rationale does not sit confortably with the well-settled judicial posture of deference to Congress where matters of revenue are at issue.

The argument for a "qualified" tax return privilege fails even if these policy grounds are conceded, however, because no showing can be made that the standard structure operates to their detriment. The efforts to frame a "qualified" tax return privilege represent a confusing and inadequately motivated departure from the standard structure of pretrial discovery. The "qualified" tax return privilege is therefore an unnecessary and undesirable barrier to what will often be the most probative, 1nost concise, and the most easily intelligible source of otherwise discoverable evidence or leads to evidence. 